\title{
Biomineralization in the Sea Hare Aplysia punctata Initiated by Nano-Dolomite
}

\author{
Anđelka M. Tonejc, ${ }^{a, *}$ Davorin Medaković, ${ }^{b}$ Stanko Popović, ${ }^{a}$ Andrej Jaklin, ${ }^{b}$ Mirjana Bijelić, ${ }^{a}$ \\ and Ivana Lončarek ${ }^{a}$ \\ ${ }^{a}$ University of Zagreb, Faculty of Science, Department of Physics, Bijenička cesta 32, 10000 Zagreb, Croatia \\ ${ }^{\mathrm{b}}$ Center for Marine Research, Ruđer Bošković Institute, G. Paliaga 5, 52210 Rovinj, Croatia
}

RECEIVED DECEMBER 6, 2013; REVISED MARCH 10, 2014; ACCEPTED MARCH 19, 2014

\begin{abstract}
X-ray diffraction (XRD), transmission electron microscopy (TEM), selected area electron diffraction (SAED), high resolution transmission electron microscopy (HRTEM), environmental scanning electron microscopy (ESEM) and energy dispersive X-ray analysis (EDS) were used in study of starting biomineralization processes in embryos of the sea hare species Aplysia punctata. 10 days old embryos appeared amorphous according to XRD patterns. TEM of the same sample showed that first grains of nanocrystalline dolomite began to form in the amorphous area. The identification of dolomite was confirmed according to TEM dark field images and SAED, as well as by HRTEM. In further development stages of the embryos very faint aragonite rings became visible by SAED. It was shown that the biomineralization process in $A$. punctata started by formation of the dolomite nanograins which served as centres of crystallization for further aragonite deposition in the larval shell. The creation of unusual intermediate crystalline phase of nano-dolomite in A. punctata embryos is of equal interest for biologist and ecologist as an evolutionary ancestral trait of molluskan biomineralization, as well as for materials scientists, as a promising template in potential bioengineering application and design of appropriate biomimetic routes that could lead to the development of new implantable biomaterials. The discussion of the present results is based on recent knowledge on general biomineralization in mollusks.
\end{abstract}

Keywords: Aplysia punctata, biomineralization, dolomite, X-ray diffraction (XRD), transmission electron microscopy (TEM), environmental scanning electron microscopy (ESEM), energy dispersive X-ray analysis (EDS)

\section{INTRODUCTION}

The marine mollusks of the genus Aplysia (Sea hare) belong to the family Aplysidae (Anaspidea, Opisthobranchia, Gastropoda). The name is derived from two long rhinophores that project upwards from the head and somewhat resemble rabbit ears. They are world-wide distributed equally in temperate and warm waters, feeding on green and red sub tidal algae. These slugs have attracted a great interest of scientists and become recognized as model organisms in numerous biological, physiological and developmental studies. Because of the simple nervous system and large neurons, Aplysia sp. has been the most widely studied mollusk in cell biology and neuroscience $e^{1,2}$ and has served as a fascinating natural source of the proteins with immunoreactivity and antitumor bioactivity features..$^{3-6}$ Evolutionary traits of this genus are that in adults Aplysia their protective outside shell was reduced to the internal shell in the form of a thin calcified plate over the gill and heart. Consequently, slugs develop diverse and effective defense strategies against predators from $\operatorname{egg}^{7-9}$ to adults including chemical and behavioral mechanisms. ${ }^{10,11}$

Sea hares are hermaphroditic animals with both fully functional reproductive glands. During the mating season they usually form chains of up to ten individuals, where every member receives sperm from the animal behind, and gives its own to the animal in front (Figure 1a). After some time animals deposit, on sea grass or seaweeds, a large amount of egg-strings (Figure 1b) containing enormous number of egg-cocoons and in each there is a species-specific number of fertilized eggs (Figure 1c). The whole embryonic development takes place within the cocoon and ends with the hatch of planktonic veliger larva. Figure 1d show the morphology of empty egg strings after hatching the veliger larvae from the cocoons. Veligers are characterized by a classic gastro-

\footnotetext{
* Author to whom correspondence should be addressed. (E-mail: andelka@phy.hr)
} 

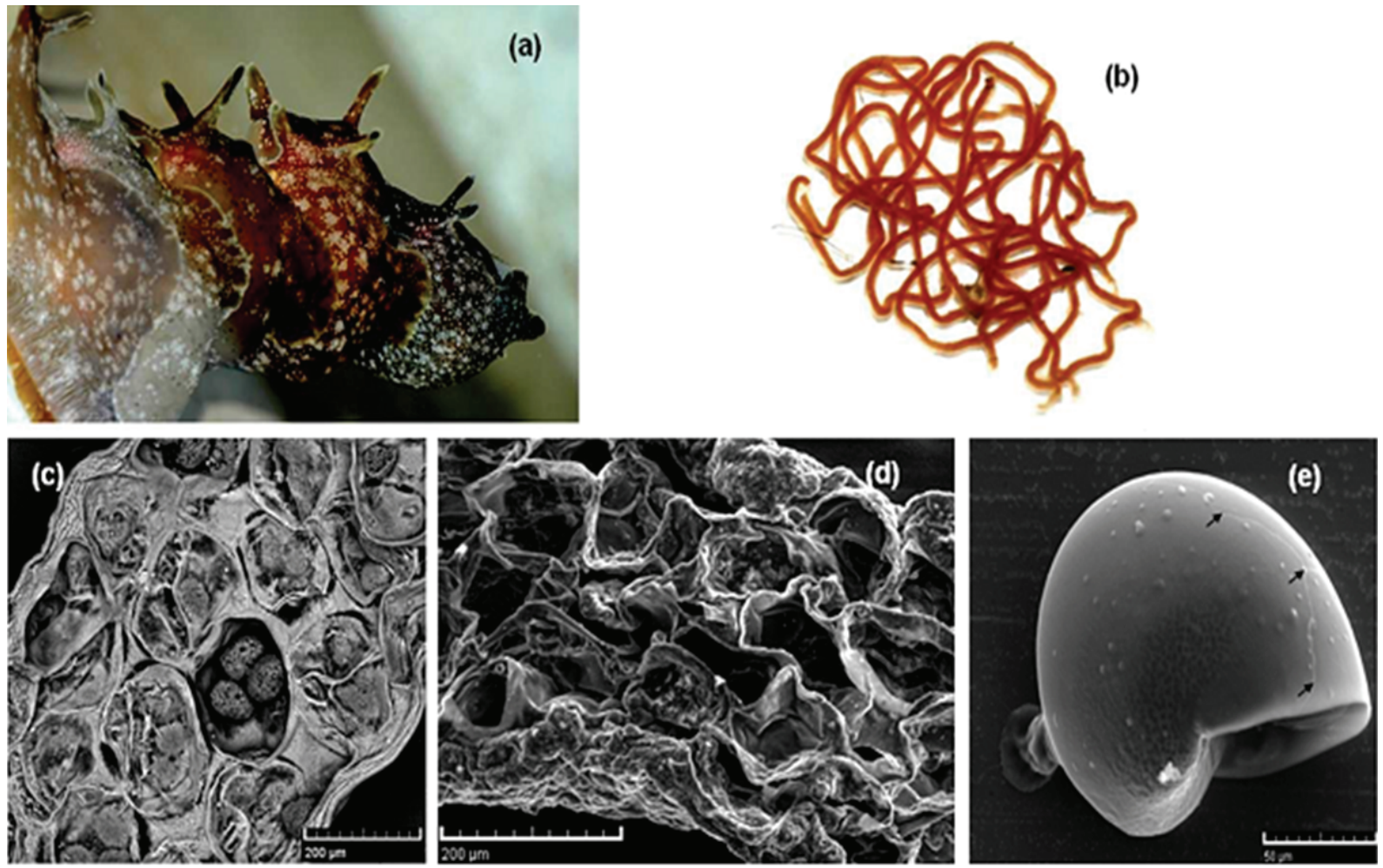

Figure 1. Sea hare Aplysia punctata. Different phases of $A$. punctata reproduction and development: a) The matting chain of adult A. punctata; b) Jelly-like egg strings, the width of the egg string is $400 \mu \mathrm{m}$; c) ESEM micrograph of the 10 days old embryos (sample C4) that are visible within the cocoon in the egg string; d) the morphology of empty egg strings after hatching the veliger larvae from the cocoons; e) characteristic "gastropod" shell shape and morphology of the sea hare after hatching veliger larvae. XRD showed that the shell is composed almost of aragonite with small amount of dolomite (sample C8). The lines of shell cracking are marked by arrows.

pod spiral minute shell that encloses the entire body and calcified operculum which closes the entrance to the shell (Figure 1e). At the end of the planktonic phase the larvae settle on the seaweeds and start to metamorphose. During metamorphosis complex morphological changes occur: mantle overgrows the shell, siphon, gills, parapodia and anterior tentacles are developed. Physiological transition in locomotion and feeding behavior designates that juvenile snails are formed. ${ }^{12-14}$

So far there are five species of sea hares known from the Adriatic Sea (Jaklin, personal data). Aplysia punctata (Cuvier, 1803) is one of the smallest members of the genus, reaching around $10 \mathrm{~cm}$ in length. The transparent and fragile internal shell of adult $A$. punctata is covered by a mantle which is only visible through the foramen, a large opening in the mantle. The body colour of $A$. punctata may vary according to the colour of algae it consumes.

The gastropods produce a shell composed largely of biogenic calcium carbonate, $\mathrm{CaCO}_{3}$, in the form of either calcite or aragonite. Vaterite, the third polymorph of calcium carbonate, was registered in the freshwater gastropod Viviparus intertextus and in newly formed layers of regenerated bivalve shells. ${ }^{15-17}$ Also, some authors showed that beside calcium carbonates, other minerals could be incorporated in the structure of mollusk shells. Odum ${ }^{18}$ found the mineral strontianite, $\mathrm{SrCO}_{3}$, in the freshwater pulmonate gastropod Physa raised in the laboratory. In the larval shell of the pearl oyster Pinctada martensi, Watabe ${ }^{17}$ observed mineral dahlite, carbonate hydroxylapatite, $\mathrm{Ca}_{5}\left(\mathrm{PO}_{4}, \mathrm{CO}_{3}\right)_{3}(\mathrm{OH})$. Barite, $\mathrm{BaSO}_{4}$, which is usually mineralized only by two protozoan organisms, was recorded in the shell of field collected freshwater Asian bivalve Corbicula fluminea. ${ }^{19}$ In laboratory experiments the same species form barite crystals with aragonite in the inner shell surface. ${ }^{20}$ Carriker et al. ${ }^{21,22}$ demonstrated a remarkable capacity of oysters to incorporate other elements in their shells. The investigation of the veliger shell composition of Spisula solidissima (Bivalvia), Ilyanassa obsoleta (Gastropoda: Prosobranchia), Dendronotus frondosus, Aoelidia papilosa and Hermissenda crassicornis (Gastropoda, Opisthobranchia) by scanning electron microprobe ${ }^{23}$ indicated, besides calcium in the form of aragonite, trace and minor elements such as $\mathrm{Na}, \mathrm{Mg}, \mathrm{P}, \mathrm{S}, \mathrm{Cl}, \mathrm{K}$ and $\mathrm{Al}$. The presence of these elements was also mentioned by 
other groups. $^{24-26}$

Numerous literature data have described in detail embryology, hatching and larval development, metamorphosis as well as possibility of cultivation of the Aplysia sp. in the controlled laboratory conditions. ${ }^{2,27,28}$ Biomineralization processes of these animals, from the formation of the first shell of the embryo to the physiological functions of the internal adult shell, are scarce, neglected and almost unknown. Watabe et al. ${ }^{29}$ reported that amorphous calcium carbonates, ACC, are the most common types of carbonate spherules in skin vesicles of sea gastropod Pomacea paludosa, and that spherules serve as source of calcium in the egg-capsule formed from vaterite. Meenakshi and Watabe ${ }^{30}$ described formation of aragonite in embryos and adult shells from these spherules, and Prince et al. ${ }^{9}$ confirmed that the spherules of Aplysia californica consist of a mixture of $\mathrm{ACC}$ and vaterite.

The accepted theory dealing with the starting biomineralization in marine invertebrates is based on the fact that, during the embryonic development, ACC precedes the first crystal formation, thus ACC being the precursor phase for further mineralization of the skeleton. ${ }^{31,32}$ Several of our earlier published papers confirmed the presence and important role of ACC in the starting biomineralization of the marine mollusks and sea urchins. Moreover, these studies revealed "unusual" initial crystals that follow ACC preceding and serving as nucleation centers for formation of the first biominerals in the embryos: e.g. barite, $\mathrm{BaSO}_{4}$, gypsum, $\mathrm{CaSO}_{4}\left(2 \mathrm{H}_{2} \mathrm{O}\right)$, basanite, $2 \mathrm{CaSO}_{4}\left(2 \mathrm{H}_{2} \mathrm{O}\right)$, and dolomite, $\mathrm{CaMg}\left(\mathrm{CO}_{3}\right)_{2}$, in the embryos and larvae of mussels Mytilus edulis ${ }^{33}$ dolomite, magnesite, $\mathrm{MgCO}_{3}$, feldspars (e.g. albite, $\mathrm{NaAlSi}_{3} \mathrm{O}_{8}$, and microcline, $\mathrm{KAlSi}_{3} \mathrm{O}_{8}$ ) in embryos and early echinopluteus, and in spines, teeth and skeleton of adult Antarctic Sea urchins Sterechinus neumayeri. $^{34}$

In the present study we have used the combination of biological and instrumental methods with an aim to register and describe the formation of the first biominerals in the marine gastropod A. punctata (Cuvier, 1803). The research has been based on recent knowledge on general biomineralization in mollusks that comprise a complex approach suggesting that both cellular activity and mineral chemistry have an important role in the initial mineral formation and further biomineralization in calcifying tissues of the organisms. However, our former experimental research of the marine, freshwater and land mollusks, and the application of modern analytical methods and techniques, have helped us to give a critical approach and multidisciplinary interpretation of the results, equally in explanation of the starting biomineralization in the A. punctata embryos and in clarification of the general biomineral mechanisms in the invertebrates.

\section{EXPERIMENTAL}

\section{Materials and Methods}

Twelve specimens of Aplysia punctata were collected in December 2008 in the vicinity of Rovinj (Croatia) in a shallow water, at a depth of 2 to $3 \mathrm{~m}$. Numerous stone blocks, scattered oversandy bottom, were covered by a dense and diverse algal overgrowth. Alive animals were immediately transferred into a $1 \mathrm{~m}^{3}$ basin with running sea water in the Centre for Marine Research, Rovinj. Animals were kept under the ambient temperature of about $10^{\circ} \mathrm{C}$ and fed with fresh algal material. The very next day animals started to form mating chains of different size, and after a week they began to deposit eggstrings on the walls of the basin. About $2 \mathrm{~cm}$ long piece of single egg-string was cut off from the same deposition every third day until hatching, which occurred on the $24^{\text {th }}$ day. The pieces of eggstrings were examined under the binoculars and then fixed with $70 \%$ ethanol.

\section{Sample Preparation for X-ray Diffraction and Elec- tron Microscopy}

Preparation of samples for X-ray diffraction (XRD) depended on the amount of the collected material or the shell volume. The preparation procedure of samples of Aplysia punctata egg strings was the same to that described for bivalve and sea urchin embryos and larvae. $^{34-36}$ The parts of egg strings were powdered in the agate mortar, spread uniformly and glued on the sample holder. Diffraction patterns were taken by means of an X-ray counter diffractometer (Philips, MPD 1880), equipped with a vertical goniometer and proportional counter, using monochromatized $\mathrm{Cu} K \alpha$ radiation. Minerals composing shells were identified according to the ICDD Powder Diffraction File.

The same powdered samples, investigated by XRD, were also used for electron microscopy. However, samples (in the form of so-called egg-strings) investigated by environmental scanning electron microscopy (ESEM), were taken from the alcohol bath and cut in two parts so that the interior of the egg-string could be observed. The egg-string was fixed on the ESEM holder. As prepared, samples were investigated by a Tescan ESEM $80 \mathrm{kV}$ microscope.

Transmission electron microscopy (TEM) accompanied by selected area electron diffraction (SAED) and high resolution transmission electron microscopy (HRTEM) were used for structural characterization of powders in a JEOL JEM-2010 $200 \mathrm{kV}$ high resolution microscope $(\mathrm{Cs}=0.5 \mathrm{~mm}$, point-to-point resolution 0.19 nm). A lanthanum hexaboride cathode was used. $A$. punctata powder samples for TEM and HRTEM investigation were prepared as follows: they were dispersed in ethanol and ground in ultrasonic bath. The dispersed 
powders were carefully set on a support copper grid coated with an amorphous holly carbon film. The micrographs were taken on very sensitive Kodak OM 163 plates. They were digitized by a UMAX Power Look III scanner (for positives and negatives) with resolution of 300 dpi for SAED diffraction and 600 to 1200 dpi for TEM and HRTEM micrographs. The dark field micrographs were taken at a magnification of 100000 and HRTEM between 300000 and 800 000. Electron diffraction patterns were calibrated by a nanocrystalline gold pattern and the camera constant was controlled during measurements with the given objective lens current.

\section{RESULTS}

\section{XRD, TEM, HRTEM and SAED}

In the present experiments eight series of Aplysia punctata embryos from the first deposition of the eggstrings until hatching of veliger larvae were analyzed. The replicas of the samples in the same development stages taken from different series (designated as A, B, $\mathrm{C}, \ldots$ to $\mathrm{H}$ ), show almost identical results and high reproducibility of the peaks and spectra for all used methods. In this work only results belonging to the $\mathrm{C}$ series were presented. XRD patterns of characteristic samples, C4, C5 and C8, of embryos are presented in Figure 2. The embryos, from 1 to 10 days old (samples $\mathrm{C} 1$ to $\mathrm{C} 4$ ), appeared amorphous in XRD spectra (C4, Figure 2). In the further development stages of embryos (sample C5), the main crystalline phase was aragonite, $\mathrm{A}$, while the strongest maximum of dolomite, D, was hardly detected in sample C8 (Figure 2). Contrary to that, TEM and HRTEM analyses of the sample $\mathrm{C} 4$ showed the precipitation of the first grains of a nanocrystalline phase inside the amorphous area that was marked by a strong maximum in SAED. Three separate regions were ana-

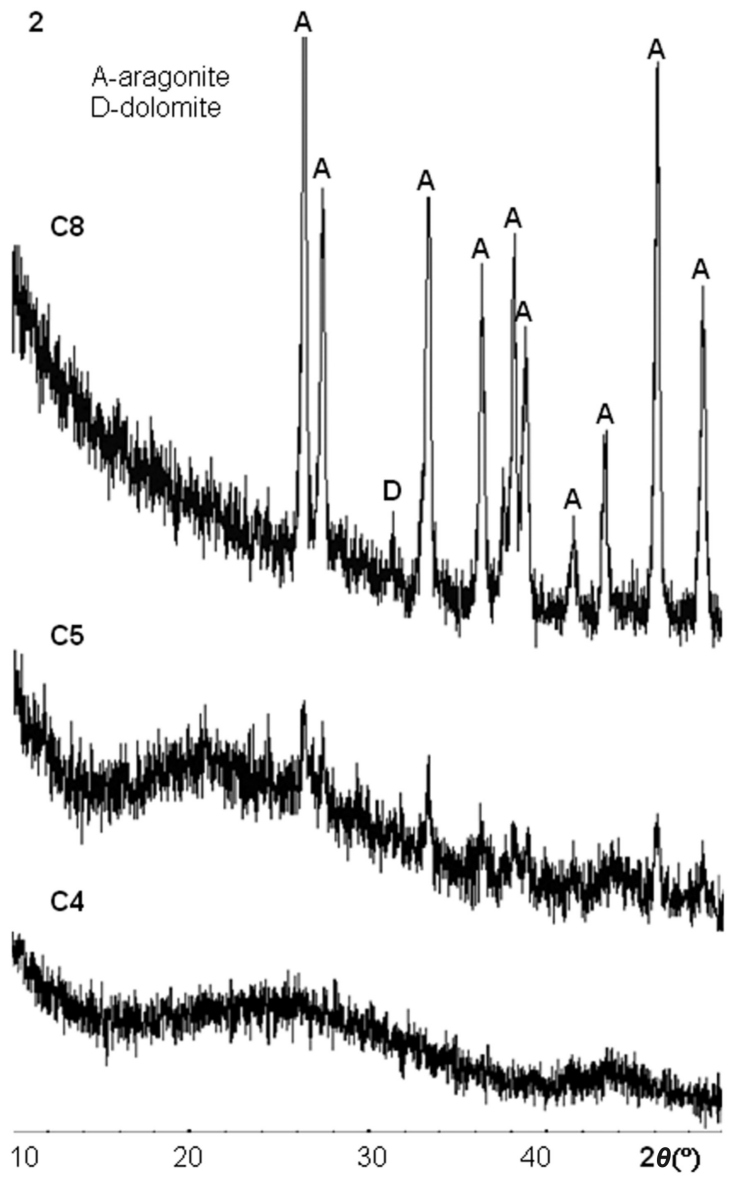

Figure 2. Characteristic parts of XRD pattern of powdered Aplysia punctata samples C4 appeared amorphous, C5 to C8, containing aragonite, $\mathrm{A}$, and dolomite, $\mathrm{D}$, in small amount.

lyzed by TEM in order to confirme the distribution of crystalline phases. The dark field photograph of the sample C4 shows a wavy amorphous region, Am, and a small fraction of grains (Figure 3a). The corresponding
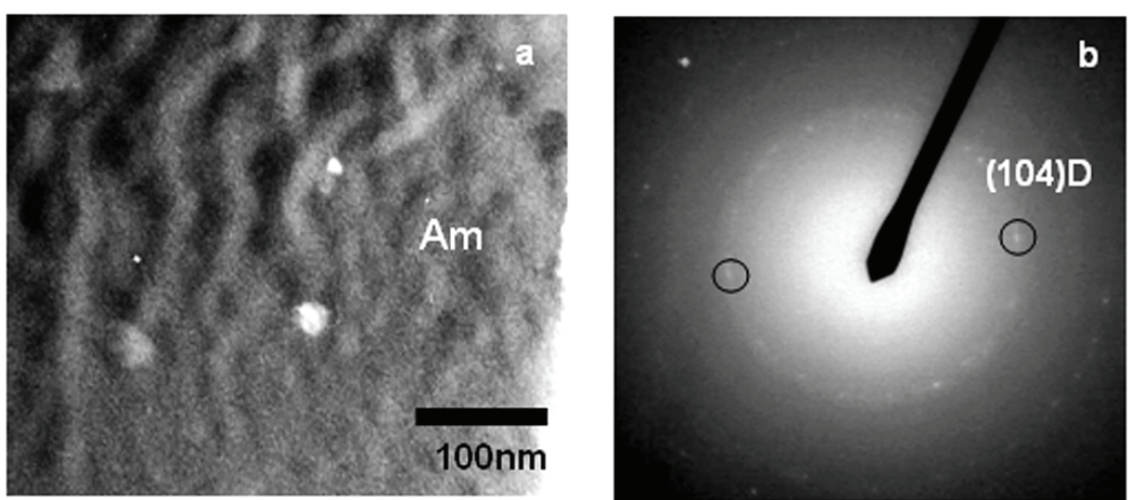

Figure 3. Detail of sample C4 (10 days old embryos in early development stage. a) The appearance of a new crystalline phase from amorphous region, Am. The dark field micrograph taken with 104 diffraction spot of dolomite, $\mathrm{D}, \mathrm{CaMg}\left(\mathrm{CO}_{3}\right)_{2}$. $\mathrm{Grains}$ of dolomite have sizes about $10 \mathrm{~nm}$. b) Corresponding SAED diffraction pattern, the strongest diffraction spots of dolomite D104 form nanocrystalline ring. 

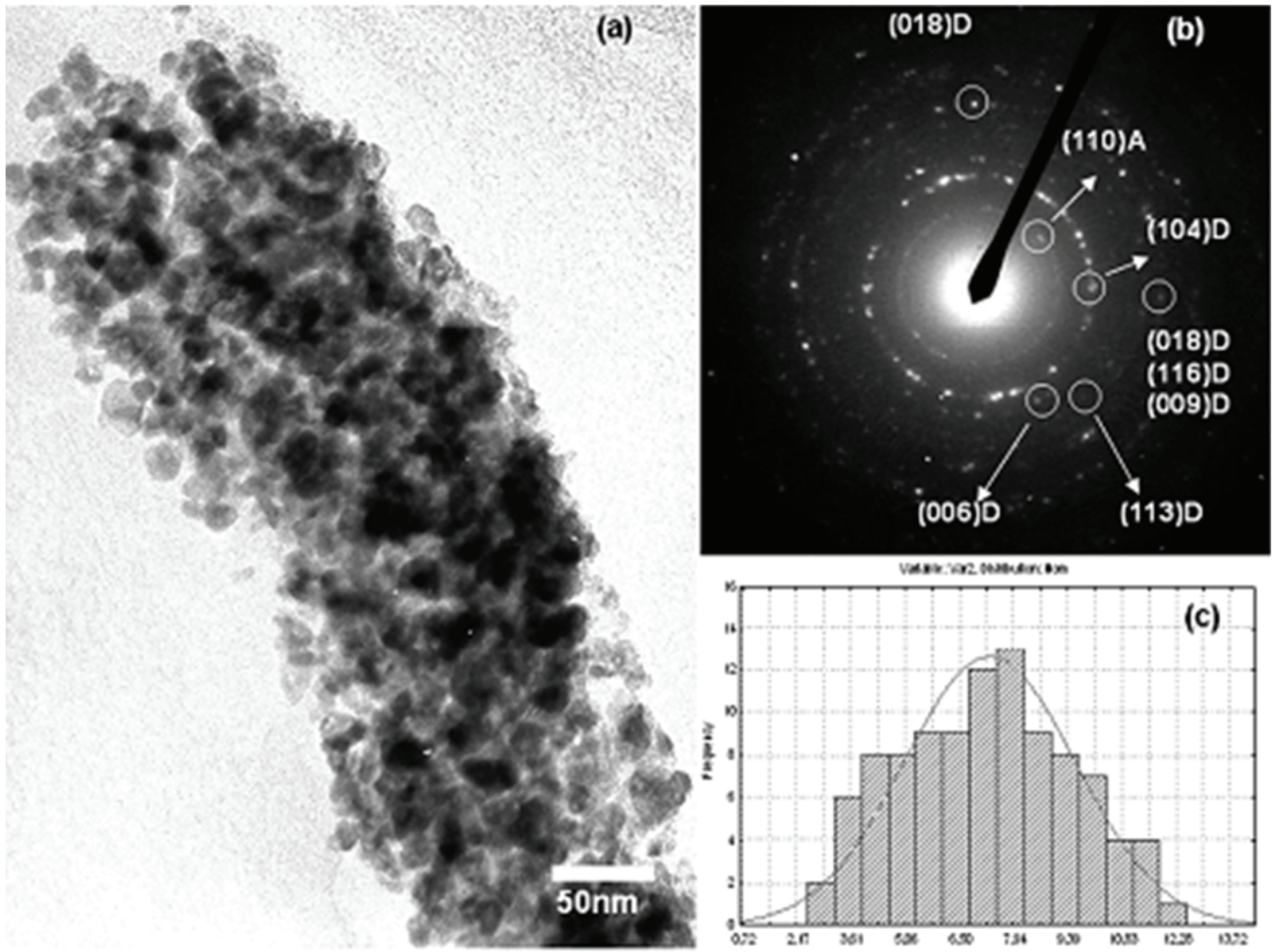

Figure 4. a) Further development of grain sizes on the edge of the sample C4 containing fine nanocrystalline grains, b) The corresponding SAED nanocrystalline diffraction shows minerals dolomite, D, and aragonite, A,. c) The measured distribution of grain sizes (from Figure 4a) fitted to the normal distribution. The average grain size was $7 \mathrm{~nm}$.

SAED pattern had a very bright background, and during observation a growing number of diffraction spots appeared (Figure 3b). The strongest diffraction spots, forming a nanocrystalline ring, were identified as dolomite D104. Grain sizes of about $10 \mathrm{~nm}$ were observed in the dark field photograph taken with the D104 maximum. The $d$-values measured by SAED were identified as dolomite, calcium magnesium carbonate, $\mathrm{CaMg}\left(\mathrm{CO}_{3}\right)_{2}$, D, according to the ICDD-PDF Card No. 84-1208.

Further, the number of precipitating grains at the edge of sample $\mathrm{C} 4$ grew with time (Figure 4a). The corresponding nanocrystalline diffraction rings were identified as D, with a small amount of A (Figure 4b). Even the strongest ring of A, the A110,was very faint, indicating that $\mathrm{A}$ is present in traces only. The measured distribution of grain sizes was fitted to the normal distribution, and the average grain size was $7 \mathrm{~nm}$ (Figure $4 \mathrm{c})$. The identification of aragonite was performed according to the ICDD-PDF Card No. 76-0606, calcium carbonate, $\mathrm{CaCO}_{3}$.

At higher magnification, after the disappearance of the amorphous phase, layers of monocrystalline D in the [010] orientation were observed and measured. SAED was performed on an area of $100 \times 100 \mathrm{~nm}^{2}$ while the corresponding HRTEM image is shown in Figure 5a. Lattice fringes of D104, marked as $d_{104}$ and with a spac- ing $0.289 \mathrm{~nm}$ and of A110, marked as $d_{110}$ with a spacing $0.421 \mathrm{~nm}$ are shown in Figure 5a. The correspond-

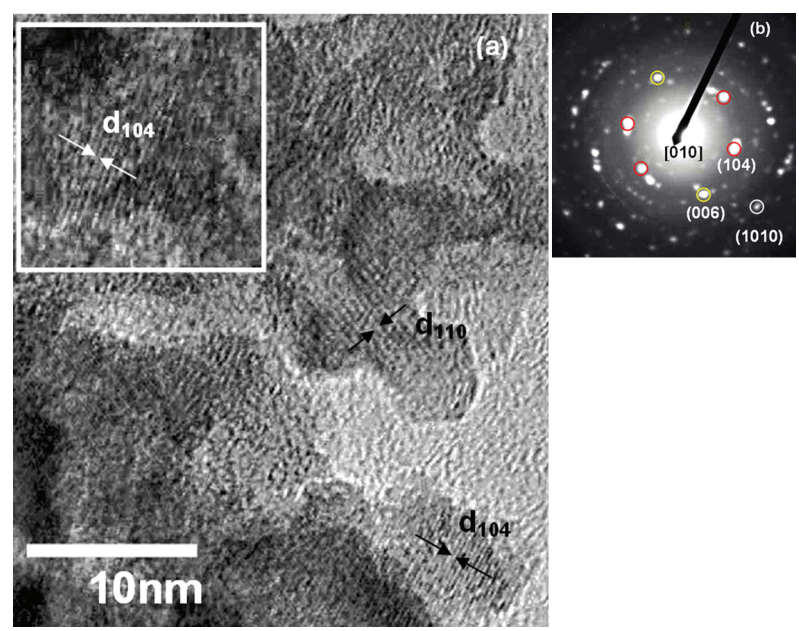

Figure 5. a) HRTEM image taken at magnification 800000. The lattice fringes of dolomite $\mathrm{D}(104)$, spacing $d_{104}=0.289$ $\mathrm{nm}$, and aragonite $\mathrm{A}(110)$, spacing $d_{110}=0.421 \mathrm{~nm}$, are marked. The lattice fringes $d_{104}$ of dolomite from the same region are displayed in the inset. b) The corresponding SAED pattern in [010] D orientation of dolomite from an area $100 \times 100 \mathrm{~nm}^{2}$. 

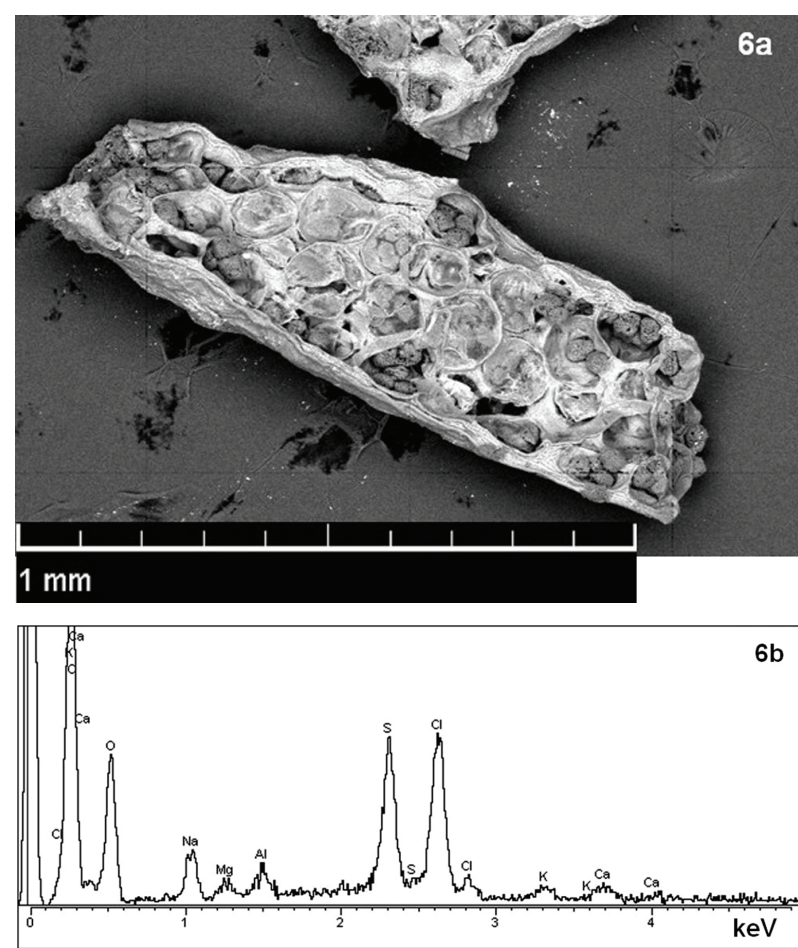

Figure 6. a) ESEM photograph of 10 days old embryos, (sample C4). b) EDS analysis pointed to surface region of the eggstring) showing all constitutive elements characteristic for the soft organic tissue, e.g., $\mathrm{C}, \mathrm{O}, \mathrm{Cl}, \mathrm{S}, \mathrm{Na}, \mathrm{Al}$, with weak lines of $\mathrm{Mg}$ and $\mathrm{Ca}$. Note: sum spectrum is an average spectrum of sum of local spectra taken at each point of the region of the sample shown in (a).

ing SAED diffraction confirmed the presence of nanocrystalline A and monocrystalline $\mathrm{D}$ with the orientation [010] (Figure 5b). The lattice fringes $d_{104}$ of dolomite from the same region are displayed in the inset.

The present results have indicated that the biomineralization process in $\mathrm{A}$. punctata starts by formation of $\mathrm{D}$ nanocrystals, which serve as centres of crystallization for further A growth. The first aragonite crystals observed by XRD appeared in 13 days old embryos (sample C5, Figure 2), and fully formed aragonite crystals were recorded in more developed embryos even before hatching, which occurred 22 days after eggstrings deposition (sample C8, Figure 2). The measured $d$-values using XRD and SAED were in accordance with the ICDD-PDF Card No. 76-0606 for aragonite $(d-$ values from SAED were measured with a standard deviation of $0.005 \mathrm{~nm}$ )

It is well known that the precipitation of crystalline phases takes place in the (over)saturated solid solution and in the amorphous material. This process is enhanced if the material is exposed to heating when the time evolution of phases is shortened. It could be assumed that the heating of samples inside the electron microscope in some way accelerates the appearance and
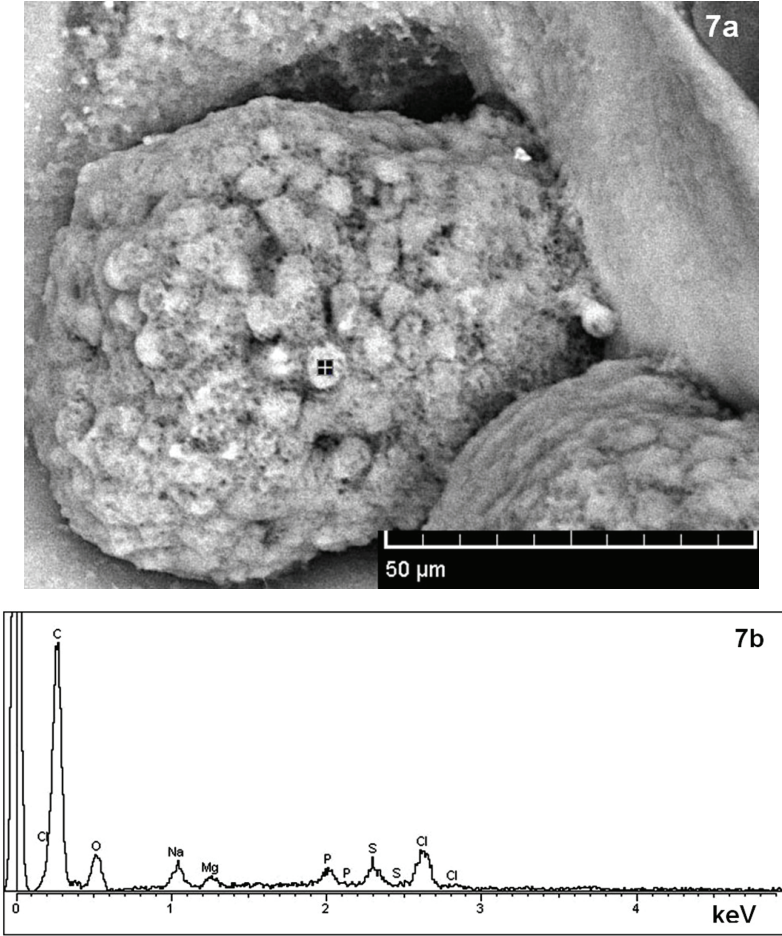

Figure 7. a) ESEM photograph of 10 days old embryos sea hare Aplysia punctata (sample C4). b) EDS analysis pointed to surface region of the embryos (indicated by a circle): no traces of $\mathrm{Ca}$ are present.

formation of first nano crystalline dolomite grains in the amorphous region of $A$. punctata embryos.

\section{ESEM and EDS}

The same C series of the samples was analysed by ESEM and EDS to support the HRTEM and SAED studies. These analysis was performed to detect the initial stages of shell biominerals growth, the main constitutive elements of crystalline phases. The aim of the combined ESEM and EDS analyses was to examine the beginning of appearance of calcium and magnesium as the main constitutive elements of crystalline phases of the shell biominerals. Special attention was paid to sample C4, that appeared amorphous in XRD without any trace of a crystalline phase, and to sample C5 showing some very faint diffraction maxima in the XRD pattern (Figure 2). The EDS sum spectrum taken from the cross section of egg-string of sample C4, at ESEM magnification of 100x (Figure 6a), showed all constitutive elements that are characteristic for the soft organic tissue, e.g., C, O, Cl, S, Na, Al, with weak lines of $\mathrm{Mg}$ and $\mathrm{Ca}$ (Figure 6b). (Note: sum spectrum is an average spectrum of sum of local spectra taken at each point of the region of the egg-string shown in the Figure 6 a).

In next experiments with the same sample EDS was performed at regions of the embryos surface (Figure 7a). A very small peak of magnesium is present and 
without any trace of calcium visible from EDS (Figure 7b).

A similar measuring procedure was applied to the cross section of sample C5 (Figure 8a) at a higher ESEM magnification. Like as in the previous development stage (sample C4), with EDS pointed to the egg envelope only elements of the soft tissue: $\mathrm{C}, \mathrm{O}, \mathrm{Cl}, \mathrm{S}$, $\mathrm{Na}, \mathrm{Al}, \mathrm{P}, \mathrm{K}$ were registered (Figure $8 \mathrm{~b}$ ). Further, EDS directed to the embryo surface (Figure 8a) showed clearly visible lines of $\mathrm{Ca}$ and $\mathrm{Mg}$ (Figure $8 \mathrm{c}$ ), indicating that beside organic tissue the first minerals were present. Magnesium, the constitutive element of dolomite, was observed in a very small amount in sample $\mathrm{C} 4$ (Figure 7b) before the appearance of calcium (sample C5, Figure 8c). That confirms the results obtained by HRTEM and SAED that dolomite is the first crystalline phase in A. punctata embryos precipitated from amorphous calcium carbonate. Also, these results are in accordance with the general model of initial biomineralization processes referred to in the relevant literature. ${ }^{31,37}$

\section{DISCUSSION}

Biomineralization processes of many marine organisms are not fully explained, especially those parts related to the first mineral formation in the early embryonic or larval development. In order to interpret the present results appropriately, a thorough discussion of biological data of Aplysia spp., and of general carbonate mineralogy, sea water chemistry, thermodynamics of the $\mathrm{Mg} / \mathrm{Ca}$ ratio, evolutionary strategic of the gastropods and recent hypothesis of general biomineralization processes in marine invertebrates are indispensable.

Kriegstein et al., ${ }^{14}$ and Capo et al. ${ }^{2}$ described that the pre-hatching development of sea hare species Aplysia californica reared in laboratory at $22{ }^{\circ} \mathrm{C}$, lasted 7 to 11 days. Watabe et al. ${ }^{29}$ found that in this species the mineral of the egg capsules was vaterite and that vaterite crystals were formed from ACC. The results of our experiments showed that sea hare Aplysia punctata cultivated at 10 to $12{ }^{\circ} \mathrm{C}$ finished its embryonal development in 22 days, as evident by hatching of veliger larvae. During this period, a change in the cell lineage and morphological formation of tissue occurred in $A$. punctata embryos. The results of XRD analysis confirmed that inside the egg capsules up to the movements of the embryos only amorphous component was present (sample C4, Figure 2). Also, XRD patterns showed that the first aragonite crystals were present in 13 days old embryos (sample C5, Figure 2), and that the fully formed larval shell 22 days after hatching contained well crystallized aragonite and small amount of dolomite (sample C8, Figure 2). The same, C, series of the samples were analyzed by TEM, SAED, ESEM and
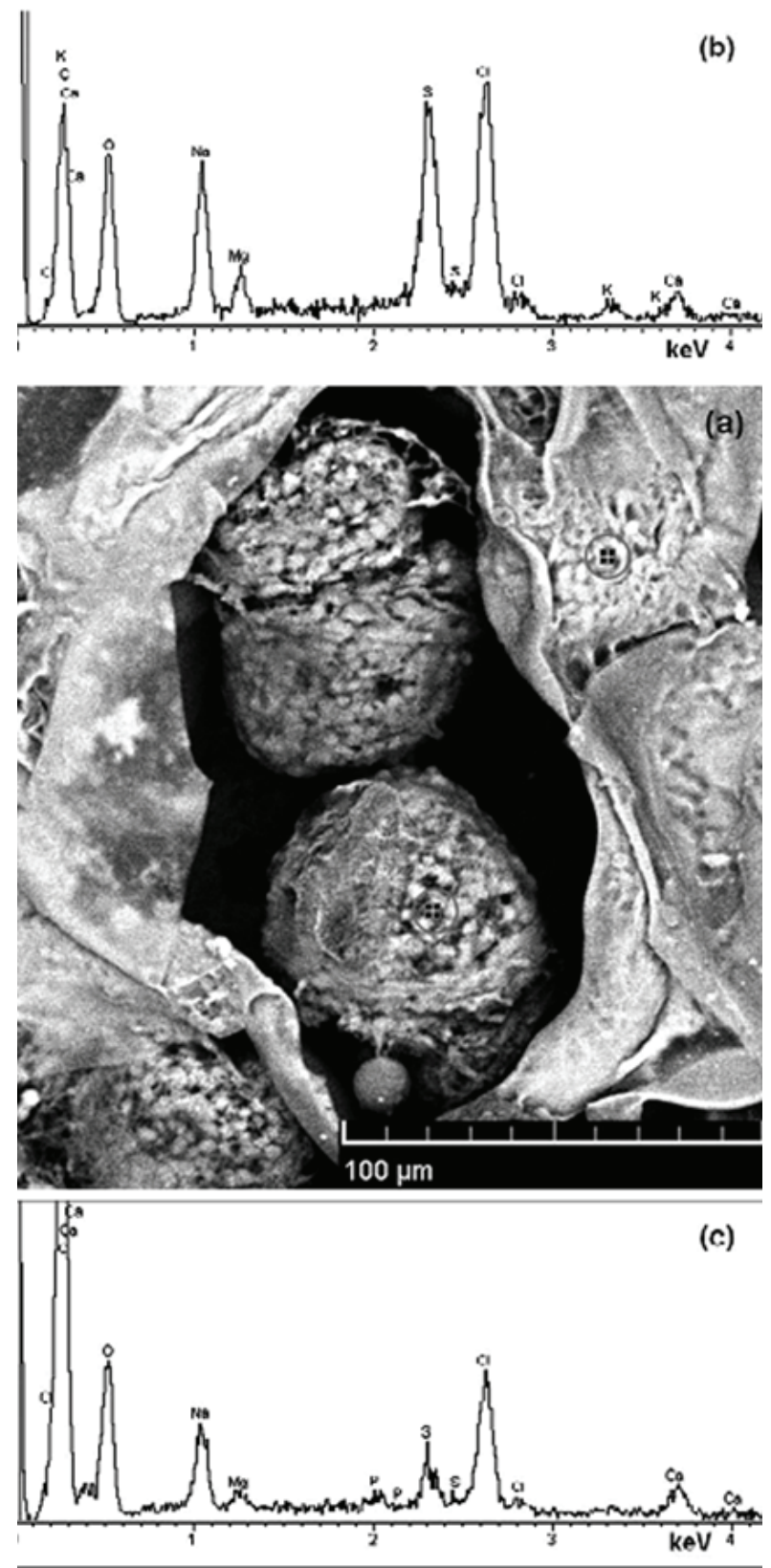

Figure 8. a) ESEM photograph of two embryos (sample C5) in the cocoon. b) EDS pointed to an egg. Contrary to former development stage (sample C4), a clear Ca peak, beside other elements, was observed on the surface of the embryo ( sample C5), confirming that the first shell around the embryo was formed. c) EDS pointed to the egg envelope showed organic structure of the tissue.

EDS; that analysis showed morphological changes during development of about 40 embryos in each capsule incorporated in a jelly-like eggstring immediately after deposition on the substrate until hatching of the veliger larvae. Moreover, results of TEM analysis of the 10 days old embryos showed appearance of a new crystalline phase developed from an amorphous region, Am. 
As shown in Figure 3, and Figure 4a, different nanosized grains were present. The grain sizes of $10 \mathrm{~nm}$ (Figure 3a) were recorded with the strongest spot D104 of the corresponding SAED nanocrystalline ring pattern. Also, the average nanograin sizes of $7 \mathrm{~nm}$ were observed (Figure 4a) with stronger dolomite rings and the faint aragonite A110 ring, in the HRTEM image showing lattice images of dolomite D104 in [010] orientation (Figure 5a, Figure 5b).

The appearance of the mineral dolomite in different living organisms is well presented in recent literature. However, authors proposed diverse hypotheses and theories of the possible dolomite formation. Deelman ${ }^{38}$ refers in details to a mechanism of natural lowtemperature formation of dolomite (e.g. by activity of sulphate or methane reducing and urea decomposing bacteria) in two species of tape worms, in freshwater snails, in pearls, in bladder stones of the Dalmatian dog, in human granulomas, tooth enamel, kidney and urinary stones. Our former research confirmed the formation of dolomite in the shells of the adult freshwater snails Belgrandiella sp., ${ }^{39}$ and as a minor component (from traces up to 5 molar \%) in calcareous algae Coralina, Lithophyllum and Pseudolithophyllum sp. from the Adriatic sea. ${ }^{40}$ However, dolomite is as a starting phase among other "unusual" biominerals registered only in the embryos of the bivalve Mytilus edulis, and in the embryos, larvae and adults of the Antarctic sea urchins Sterechinus neumayeri. ${ }^{33,34}$

We can use a different approach in order to explain the presence of dolomite in the early embryos of the $A$. punctata. It is well known that carbonate minerals are seldom pure but tend to incorporate other cations within their crystal lattice. The rhombohedral calcite tends to incorporate cations usually with smaller ionic radii, and orthorhombic aragonite large cations. Magnesium, $\mathrm{Mg}$, as a small cation, substitutes $\mathrm{Ca}$ in the calcite crystal lattice and this process can result either in low Mg-calcite ( $\mathrm{Mg}$ content $<1$ molar \%) or in high $\mathrm{Mg}$ calcite (4 to 20 molar $\%$ of $\mathrm{Mg}$ ). As the concentration of $\mathrm{Mg}$ ions in the sea water is almost five times bigger than that of $\mathrm{Ca}$ ions, a number of marine organisms form their hard structures and skeletons of high Mg-calcite. In case that the amount of $\mathrm{Ca}$ ions is similar to that of $\mathrm{Mg}$ ions in the rhombohedral crystal lattice, dolomite is formed as a relatively a stable mineral. $\mathrm{Mg}$ ion is smaller than $\mathrm{Ca}$ ion. So the lattice spacings in pure dolomite are considerably smaller than those in calcite. It is a fact that organisms are capable to selectively precipitate different minerals; their specific regulation can overcome the strict physical parameters of ambient ion concentrations. Because of thermodynamically reasons, organisms favour energetically favorite processes. According to the Ostwald step rule related to the nucleation and growth of crystalline phases, the organisms form a sequence of metastable phases before the formation of the final stable phase. ${ }^{32,41}$ This could explain the dolomite deposition from amorphous calcium carbonate in A. punctata.

Another approach comprises the influence of $\mathrm{Mg} / \mathrm{Ca}$ seawater chemistry oscillation during geological periods on skeletal secretion of different marine organisms (algae, sponge, corals, bryozoans, mollusks) that are reflected in initial evolution on phosphatic to calcitic invertebrate biominerals. ${ }^{42} \mathrm{Mg} / \mathrm{Ca}$ ratio in the seawater appears to control also the evolution of biomineralization; it may favour the evolution of the calcitic skeleton in one geoperiod or high Mg-calcite or aragonite skeleton in another geoperiod. ${ }^{43}$ Yongding et $\mathrm{al}^{44}$ observed, on the basis of marine sediments, that the mineral components in fossils show an evolution sequence in direction: silica and dolomite-phosphateorganic matter - calcite - magnesium calcite and aragonite. Thomas et al. $^{45}$ showed that the evolution and strategy for constructing the hard skeleton are imprinted in the organism RNA sequences and patterns of early embryonic development. Recurring features of parallel evolution of complex organic and inorganic skeletons are controlled by genes that were already established in ancestral organisms. An important aspect of the evolutionary history of biomineralization is the finding that the first up to now known mineralized organism Cloudina contained in its shell walls of organic materials with microdolomite crystals only. ${ }^{46,47}$

All above findings may explain the formation of a dolomite-like phase as the precursor of the first aragonite biomineral in A. punctata. Transient precursor mineral phases have been registered and described in several groups of the marine invertebrates, ${ }^{31,48}$ and these phases are fundamental to understand the processes in vertebrate bone and tooth mineralization. ${ }^{49,32}$ The first precursor minerals are poorly ordered phases (e.g. nanograins of dolomite in $A$. punctata); these grains serve as nucleation centres for final mineral aragonite of the A. punctata veliger larvae. The transport of the nanograins to the growing mineral surface is more efficient and thermodynamically favoured than the transport of individual ions at low concentration. ${ }^{41}$

The present results could be of great importance for a better understanding of fundamental mechanisms and processes of the starting formation of biominerals in the mollusks and in advanced biomimetic studies.Various approaches to explain biomineralization have been motivated by observations of the biological world and molecular recognition at the organicinorganic interface in "model" organisms that offer a broad range of possibilities to control and produce new materials. The transient nanodolomite formation in Aplysia punctata embryos represents exquisite strategies of organisms that by strongly interacting precursors 
catalyze complex calcium carbonate morphological development, which could represent a model in synergistic studies of biomineralization and biomimetics. It has become an exciting area of research for the material scientists trying to mimick biological pathways similar to those used by mineralizing organisms.

\section{CONCLUSION}

Understanding the initial crystal formation and basic physical principles of crystallization from saturated solutions up to the final stable structure is very important for description of biomineralization in the biological systems. ${ }^{50}$ In the formation of biominerals in the marine invertebrates several steps can be distinguished: 1) formation of amorphous calcium carbonate (ACC) in early embryos; 2) production of nuclei (nanospheres) from ACC; 3) these nuclei serve for further carbonate formation. All parts of these processes include close interaction with organic macromolecules. ${ }^{51,52}$

In the present work XRD, TEM and HRTEM with SAED were used to find and locate the starting biominerals in the embryos of sea hare Aplysia punctata. Magnesium, as the constitutive element of dolomite, was observed in the embryos before the appearance of calcium. Nanodolomite was the first crystallographic phase that precipitated from amorphous calcium carbonate. The findings of an unusual initial biomineral, dolomite, in embryos of the Nudibranch gastropod $A$. punctata lead us to the conclusion that in specific conditions recent marine invertebrates are capable of behaving in accord with ancient features and models of the biomineral formation in the early ancestors. Moreover, experimental results clarify and explain the well known biomineralization hypotheses:

- calcium carbonate (and phosphate) ions are abundant in the oceans and thus would be favoured in biomineralization over much rarer materials, ${ }^{53,54}$

- origins of calcareous skeletons reflect multiple independent cooptations of molecular and physiological processes which are widely shared among eukaryotic organisms. ${ }^{55,56}$

Acknowledgements. The authors thank the Croatian Ministry of Science, Education and Sport (Project No. 119-9828861009 and No. 098-0982705-2727) for financial support of this work. The authors also thank to Professor V. Bermanec and Dr. H. Posilovic for taking ESEM images.

\section{REFERENCES}

1. L. L. Moroz, J. R. Edwards, S. V. Puthanveettil, A. B. Kohn, T. Ha, A. Heyland, B. Knudsen, A. Sahni, F. Yu, L. Liu, S. Jezzini, P. Lovell, W. Iannucculli, M. Chen, T. Ngyen, H. Sheng, R. Shaw, S. Kalachikov, Y. Panchin, W. Farmerie, J. J. Russo, J. Ju, and E. R. Kandel, Cell 127 (2006) 1453-1456.
2. T. R. Capo, A. T. Bardales, P. R. Gillette, M. R. Lara, M. C. Schmale, and J. E. Serafy, Comp. Biochem. Phys. C 149 (2009) 215-222.

3. M. Yamazaki, Comp. Biochem. Phys. C 105 (1993) 141-146.

4. D. Butzke, N. Machuy, B. Thiede, R. Hurwitz, S. Goedert, and T. Rudel, Cell. Death. Differ. 11 (2004) 608-617.

5. K. B. Suenaga, Chem. Soc. Jpn. 77 ( 2004) 443-451.

6. K. Zandi, M. H. Farsangi, I. Nabipour, M. Soleimani, K. Khajeh, R.H. Sajedi, and S.M. Jafari, Afr. J. Biotechnol. 6 (2007) 1280-1283.

7. P. M. Johnson and A. O. D. Willows, Mar. Freshw. Behav. Phy. 33 (1999) 147-180.

8. R. Przeslawski and K. Benkendorff, J. Mollus. Stud. 71(2004) 75-83.

9. J. S. Prince, M. J. Lynn, and P. L. Blackwelder, J. Moll. Stud. 72 (2006) 405-412.

10. H. Wagele, M. Ballesteros, and C. Avila, Oceanogr. Mar. Biol. 44 (2006) 197-276.

11. S. Shabani, S. Yaldiz, L. Vu, and C. D. Derby, J. Comp. Physiol. A 193(2007) 1195-1204.

12. M. Miller, Proc. Malacol. Soc. Lond. 34 (1960) 165-167.

13. L. H. Hyman, The Invertebrates. Volume VI. Mollusca I, McGraw-Hill NY,USA, (1967).

14. A. R. Kriegstein, V. Castellucci, and E. R. Kandel, PNAS 71 (1974) 3654-3658.

15. K.M. Wilbur in: Physiology of Mollusca, Vol. 1, K. M. Wilbur and C. M. Yonge (Eds.), Academic Press, New York, (1964) 243-282.

16. J. D. Taylor, W. J. Kennedy, A. Hall, Bull. Brit. Mus. (Nat. Hist.), Zool. 3 ( 1969) 1.

17. N. Watabe in The Mollusca, Vol. 11, K. M. Wilbur (Ed.), Academic Press, New York, (1988) 69-104.

18. H. T. Odum, Science 114 (1951) 211-213.

19. L. W. Fritz, L. M. Ragone, and R. A. Lutz, Limnol. Oceanogr. 35 (1990) 756-762.

20. L. W. Fritz, G. Ferrence, and T. R. Jacobsen, Limnol. Oceanogr. 37 (1992) 442-448.

21. M. R. Carriker, R. E. Palmer, L. V. Sick, and C. C. Johnson, J. Exp. Mar. Biol. Ecol. 46 (1980) 279-296.

22. M. R. Carriker, C. P. Swann, R. S. Prezant, and C. L. III. Counts, Mar. Biol. 109 (1991) 287-297.

23. I. S. Eyster, Biol. Bull. 170 (1986) 211-231.

24. J. A. C. Nicol, The Biology of Marine Animals, Sir Isaac Pitman and Sons, Ltd, London, 1967, pp. 699.

25. M. R. Carriker, C. P. Swann, and R. S. Prezant, Am. Malacol. Bull. 1 (1983) 102.

26. G. Roesijadi and E.A. Crecelius, Mar. Biol. 83 (1984) 155-161.

27. N. E. Strenth and J. E. Blankenship, Veliger 21 (1978) 99-103.

28. P. Kendel, T. R. Capo, Veliger 22 (1979) 194-198.

29. N. Watabe, V. R. Meenakshi, P. Blackwelder, E. M. Kurtz, and D. Dunkleberger in: The mechanism of mineralization in invertebrate and plants, N. Watabe and K. M. Wilbur (Eds.), University of South Carolina Press, Columbia (1976) 283-308.

30. V. R. Meenakshi and N. Watabe, Biomineralization 9 (1977) 48-56.

31. I. M. Weiss, N. Tuross, L. Addadi, and S. Weiner, J. Exp. Zool. 293 (2002) 478-491.

32. S. Weiner, Bone 39 (2006) 431-433.

33. D. Medaković, PhD Thesis, University of Zagreb and Ruder Boškovic Institute (Croatia), (1995).

34. D. Medaković, S. Popović, and D. T. Manahan in: Antarctic Biology in a Global Context, A. H. L. Huiskes, W. W. C. Gieskes, J. Rozema, R. M. L. Schorno, S. M. van der Vies, and W. J. Wolf (Eds.), Backhuys Publ, Leiden, The Netherlands (2003)140-143.

35. D. Medaković, S. Popović, B. Gržeta, M. Plazonić, and M. HrsBrenko, Mar. Biol.129 (1997) 615-623. 
36. A. M. Tonejc, D. Medaković, S. Popović, M. Bijelić, Ž. Skoko, H. Posilović, A. Jaklin, and A. Tonejc in: Proc. Microscopy Conference Graz, Vol. 2, M. A. Pabst and G. Zellnig (Eds.) (2009) 67-68.

37. L. Addadi, D. Joester, F. Nudelman, and S. Weiner, Chem. Eur. J. 12 (2006) 980-987.

38. J. C. Deelman, "Low-temperature formation of dolomite and magnesite", can be found under

(http://www.jcdeelman.demon.nl/dolomite/bookprospectus.html) (2008).

39. D. Medaković, R. Slapnik, S. Popović, and B. Gržeta, Comp. Biochem. Phys. A 134 (2003)121-127.

40. D. Medaković, S. Popović, N. Zavodnik, B. Gržeta, and M. Plazonić, Mar. Biol. 122 (1995) 479-485.

41. A. Navrotsky, PNAS 101 (2004) 12096-12101.

42. S. Kempe and J. Kazmierczak, Bull. Inst. Oceanogr. Monaco 13 (1994) 61-117.

43. S. M. Stanly and L. A. Hardie, Palaeogeogr. Palaeocl. 144 (1998) 3-19.

44. D. Yongding, J. Xieguang, Z. Shengbai, Y. Hong, L. Juying, and H. Kui, Chin. J. Geol. 12 (1977) 219-235.
45. R. D. K. Thomas, R. M. Shearman, and G. W. Stewart, Science 288 (2000) 1239-1242.

46. S. W. F. Grant, Am. J. Sci. 290 A (1990) 261-294.

47. A. H. Knoll, Rev. Mineral. Geochem. 54 (2003) 329-356.

48. E. Beniash, J. Aizenberg, L. Addadi, and S. Weiner, Proc. R. Soc. Lond. 264 (1997) 461-465.

49. N. J. Crane, V. Popescu, M. D. Morris, P.Steenhuis, and M. A. Ignelzi, Bone 39 (2006) 431-433.

50. J. J. De Yoero and P.G. Velikov, Rev. Mineral. Geochem. 54 (2003) 57-93.

51. L. Addadi, S. Raz, and S. Weiner, Adv. Mater. 15 (2003) 959-970.

52. C. Rodriguez-Navarro, C. Jimenez-Lopez, A. Rodriguez- Navarro, M. T. Gonzales-Munoz, and M. Rodriguez-Gellego, Geochim. Cosmochim. Ac. 71 (2007) 1197-1213.

53. H. A. Lowenstam and L. Margulis, Biosystems 12 (1980) 27-41.

54. H. A. Lowenstam, Science 211 (1981) 1126-1131.

55. P. Westbroek and F. Marin, Nature 392 (1998) 861-862.

56. F. Marin, G. Luquet, B. Marie, and D. Medaković, Curr. Top. Dev. Biol. 80 (2008) 209-276. 